\title{
The Impact of Social Responsibility on the Market Value for Services Corporations, Service Type as a Marketing Variable
}

\author{
Dr. Ali Mustafa Magablih ${ }^{1}$ \\ ${ }^{1}$ Irbid National University, Jordan \\ Correspondence: Dr. Ali Mustafa Magablih, Irbid National University, Jordan. E-mail: Alimagablih@yahoo.com
}

Received: October 19, 2021

Accepted: November 15, 2021 Online Published: November 30, 2021

doi:10.5430/jbar.v11n1p1

URL: https://doi.org/10.5430/jbar.v11n1p1

\begin{abstract}
The study aims to know the impact of social responsibility as a cost and also to show the market value of the Jordanian services corporations listed on the Amman Stock Exchange. "Services type" was used as a variable for the relationship rate in this study. The descriptive approach was used and applied to the data of 37 companies during the period from 2012-2019. The researcher also used statistical methods such as the arithmetic mean and standard deviation to describe the study data, and the test of linear regression and correlation analysis, in order to test the study hypotheses. Among the most important results that have been reached, there is an impact of social responsibility as costs and the disclosure of the market value of services companies. The study also showed a modified effect of services type on the relationship between social responsibility disclosure and market value.
\end{abstract}

Based on the preceding, the study recommended expanding the social responsibility disclosure, which helps the company build a strong name as a desirable institution, which enhances the image of the company and the name of the product in the services market and among customers.

Keywords: social responsibility, costs of social responsibility, disclosure of social responsibility, market value, type of services, Jordanian services corporations.

\section{Introduction}

The social responsibility of organizations emphasizes the importance of the concept of community participation by business organizations, and a proposal has been put forward that goes beyond the company's role of achieving profits and increasing wealth in order to play a role in making decisions that would clarify the relationship between social responsibility and the institution in an ethical manner, and improve the contribution Improving the quality of its workforce and society as a whole. It turns out that this can be achieved through several activities and areas of social responsibility for organizations, and through integration into society to achieve the interests of customers, employees, shareholders, and governments, and through the foregoing, it is possible to determine the social responsibility of decision-makers to enhance the application of work follow-up policies in support of their various fields, which are desirable in the society.

The importance of social responsibility as a modern concept has increased, especially at the level of business organizations, to find products that provide a good addition to social value and to achieve the maximum possible benefit. This benefit is intended, both in terms of achieving the requirements of the local community and the surrounding environment, to achieve the goals of the institution in which it works to achieve the goals of business organizations, which is reflected positively on their improvement and continuity. For the sake of the above, part of the activities of business organizations has been directed towards their social responsibilities, and it is expected that an improvement will appear in the performance and results of the work of these organizations, and this is due to the consolidation of a good mental image of the members of society and gain their confidence, which attracts a wider segment of clients.

The interest of business organizations in social responsibility is reflected in the financial and accounting aspects, so this must also be reflected in the financial reports prepared by various companies and organizations on a regular basis.

What is meant by financial reports, whether related to multiple aspects of social responsibility prepared in the form 
of financial values that are spent and monitored or in the form of financial or non-financial disclosures presented in financial reports? Given the different nature of the opinions of companies and organizations about social responsibility and the different focus on it from one company to another, this study was presented to discuss social responsibility as a cost, to disclose the market value of the services corporations offered in the Amman Stock Exchange, to identify the impact of the type of services on the nature of this relationship.

\subsection{Study Problems and Questions}

It is clear from the commitment of services corporations towards society that it is a major priority that cannot be denied, as companies seek to fulfill their responsibilities towards society because of their importance in increasing the benefit and raising the loyalty of customers and thus continuing to achieve the goals. In view of the lack of attention to the required level of social responsibility, this study was created to present and discuss the following:

The first question: What is the impact of social responsibility costs on the market value of services corporations listed on the Amman Stock Exchange?

The second question: What is the impact of social responsibility disclosure on the market value of services corporations listed on the Amman Stock Exchange?

The third question: What is the average impact for the type of services on the relationship between social responsibility disclosure and the market value of services corporations listed on the Amman Stock Exchange?

\subsection{Objectives of the Study}

The study aims to find out the impact of social responsibility on the value of the services corporations listed on the Amman Stock Exchange. The type of services was chosen as a modified variable, and accordingly, the study will attempt to reach the following objectives:

First: Identifying the impact of social responsibility costs on the market value of services corporations listed on the Amman Stock Exchange.

Second: Clarifying the impact of social responsibility disclosure on the market value of services corporations listed on the Amman Stock Exchange.

Third: A statement of the impact of the type of services on the relationship between social responsibility disclosure and the market value of services corporations listed on the Amman Stock Exchange.

\subsection{The Importance of the Study}

The importance of the study is illustrated by:

A. The importance of the current study from the researcher's point of view is that it is distinct from its predecessors who dealt with social responsibility and its impact on raising the market value of services corporations listed on the Amman Stock Exchange, and using the type of services as a modified variable. Therefore, this study is a distinctive addition to the local library.

B. Practical importance :From the researcher's point of view, the results that will be reached through the analysis of scientific data for the study variables will reduce the degree of certainty of decision-makers, whether they are investors or lenders, which helps reduce and rationalize the decisions taken towards their current and future benefits, financially and socially

\subsection{Study Hypotheses}

Based on the study questions and its model, the study hypotheses can be written as follows:

Ho1: There is no statistically significant effect $(0.05 \geq \alpha)$ for the cost of social responsibility on the market value of services corporations listed on the Amman Stock Exchange.

Ho2: There is no statistically significant effect $(0.05 \geq \alpha)$ to disclose the social responsibility on the market value of the services corporations listed on the Amman Stock Exchange.

Ho3: There is no statistically significant effect $(0.05 \geq \alpha)$ for the variable of the type of services on the relationship between social responsibility disclosure on the market value of services corporations listed on the Amman Stock Exchange.

\section{Previous Studies}

Jumaa's study (2017) entitled: The impact of Jordanian companies' adoption of social responsibility on their 
financial performance (an empirical study on companies listed on the Amman Stock Exchange)

This study aims to know the impact of Jordanian companies' adoption of social responsibility and its reflection on financial performance. This study was applied to companies listed on the Amman Stock Exchange. The study sample is 149 companies according to Robert Mason's equation. These companies were distributed into categories based on the stratified sample method. To achieve the objectives of the study, the descriptive analytical method was relied on. The results of the study showed a statistically significant effect of adopting social responsibility on the financial performance of these companies as measured by the return on assets (ROA). And the existence of an impact for each of the activities related to environmental protection and the activities related to the development of human resources on the financial performance, and the presence of a statistically significant impact of adopting social responsibility on the financial performance as measured by the return on equity (ROE). The study recommended the officials of the Amman Stock Exchange and other relevant bodies to activate the supervision of the companies' commitment to disclose their social activities that they carry out and to motivate the companies to do so, and to raise awareness about the effects and repercussions that follow the conduct of social activities because of their impact on their financial performance.

Al Mubaidin and Al Dhahrawi study (2017) entitled: "The impact of the disclosure of the extractive and mining industries companies listed on the Amman Stock Exchange about the costs of social responsibility on the financial performance of the sector"

The study aims to know the nature of the disclosure of the Jordanian public shareholding companies in the extractive and mining industries sector about the costs of social responsibility in their financial statements. This social responsibility is represented in (consumer protection, environmental protection, community service, and worker protection) and its impact on financial performance. The descriptive analytical approach was applied in order to achieve the objectives of the study. Data of 34 financial and administrative managers working in 17 companies in the above-mentioned sector were collected. The results of the study showed that there is an impact of disclosing the costs of social responsibility related to consumer protection, environmental protection and community service on the financial performance of the sector. The results of the study also showed that there was no effect of disclosing the costs of protecting workers on the financial performance of the sector companies. The study included a set of recommendations, the most important of which is that there is a need for companies to commit to disclosing the costs of social responsibility related to each of (consumer protection, environmental protection, serving the surrounding community) because of its important role in improving the financial performance of sector companies.

Gutsche\& Gratwohl (2017). Firm-value effects of CSR disclosure and CSR performance

The study aimed to test the impact of corporate social responsibility disclosure on the company's value, measured by the average stock values over the four months following the end of the fiscal year, using a sample of (500) American companies listed in the S \& P index during the period 2011-2014. The study found a positive and moral relationship between the disclosure of social responsibility and the value of the company, and the study added another dimension by studying the impact of social responsibility disclosure, and the study found that the positive impact of social responsibility disclosure is stronger in companies with poor performance of social responsibility compared to companies with high performance of corporate social responsibility, the study recommended conducting future research on the usefulness of corporate social responsibility information.

Nekhili\& Rebolledo (2017). Corporate social responsibility disclosure and market value: Family versus nonfamily firms.

The study aimed to study the relationship between the corporate social responsibility report and the value of the company measured by the Tobins Q ratio, and whether this relationship differed between family businesses and non-family businesses using a sample of 91 of the largest French companies over a period of ten years (2001-2010). Family businesses display less information regarding corporate social responsibility compared to non-family businesses. The study also found a positive relationship between disclosure of social responsibility and the value of the company in family businesses, and the study found a negative relationship between the two variables in non-family businesses.

Yiwei Liet al, (2018). "The Impact of Environmental, Social and : ( Koh Governance Disclosure on Firm Value: The Role of CEO Power

The study aimed to demonstrate the environmental, social and corporate governance disclosures on the value of the company, by studying a large group of sectors consisting of 350 companies listed in the Financial Times Securities in 
the United Kingdom, and studying whether the environmental, social and corporate governance disclosure affects the value of the company. To test the hypotheses, the researcher relied on regression analysis using a variable to reduce the error rate, and the use of the Hickman model, and the study concluded that there is a positive correlation between the degree of environmental and social disclosure and about governance on the value of the company. In enhancing the value of the company, the study also found that executives' support for disclosures affects the value of the company, where the owners of these facilities believe that the disclosures are related to the strength of the authority granted to the executive management, with the need to adhere to the disclosure of environmental and social reports.

Issa's study (2019) entitled: "The Impact of Disclosure of Governance and Social Responsibility on the Market Value of Services corporations Listed on the Amman Stock Exchange"

The aim of this study is to know the impact that disclosure of corporate governance and social responsibility standards has on the market value of services corporations on the Amman Stock Exchange list, where this study was conducted on 56 of those companies. The descriptive analytical approach was applied to achieve the objectives of the study. The study showed that there is a statistically significant effect of disclosing the standards of governance and social responsibility, and this effect is reflected on the market value of the companies listed on the Amman Stock Exchange. As well as with regard to social responsibility, it has been found that if the company discloses social responsibility in its financial reports, it will have a positive impact on the company's image with stakeholders, which improves the market value of the company. One of the most important recommendations of the study is directing investors' attention to the information contained in the annual financial reports, which contributes to rationalizing their investment decisions, this is due to the need to educate them to increase their focus on the items contained in the financial and non-financial reports, and not to focus on financial indicators only. The study also recommended the importance of activating laws that oblige companies to disclose standards of governance and social responsibility, and the need to conduct new independent studies on the impact of corporate governance and social responsibility on the financial value of companies.

Tahrawi \& Swailhy study (2019) entitled: "An analytical study of the impact of the costs of social responsibility on the performance of companies"

The aim of this study is to find out the impact of the costs of social responsibility on the performance of companies, this is based on a three-standard policy, in which the impact of social, environmental and financial performance is reflected. When companies adopt social responsibility towards workers, society and the environment, this gives them an improvement in their performance. Therefore, the costs of this responsibility, according to many studies, would give it a positive advantage, raise its financial performance, and provide it with an opportunity to invest in the long-term, even if it is a problem and measuring these costs in the short-term. The researcher relied on the descriptive approach to describe social responsibility and its costs and the variables associated with it. He also used the analytical method by analyzing the impact of the costs of corporate social responsibility on their performance in general and financial performance in particular. Corporate social costs can be divided between social costs and economic costs.

Jassim \& others study (2020) entitled: "The Role of Accounting Disclosure of Social Costs on Consumer Purchase Decisions (Applied Research that included a Sample of Iraqi Services Companies)"

The study aims to know the impact of accounting disclosure about the social responsibility of services corporations on consumer purchasing decisions. To achieve the goal of the study, the inductive approach was applied for the theoretical side, and the analytical approach for the practical side. This is to test the research hypotheses on a sample of Iraqi services corporations listed in the Iraq Stock Exchange for the years $(2016,2017,2018)$. After testing the hypotheses, the study concluded that social responsibility accounting is one of the most important elements that requires Iraqi companies to make more effort to pay attention to it, because it represents a commitment to social aspects towards external parties. In a way that contributes to achieving consumer satisfaction.

Al-Braik study (2020) entitled "The impact of accounting disclosure on social responsibility on the characteristics of Egyptian joint stock companies (experimental study)"

The study aimed to study the impact of disclosure of corporate social responsibility activities on the characteristics of Egyptian joint stock companies. The sample of (50) Egyptian joint stock companies over the period (2013, 2014, 2015) respectively, and the researcher used the multiple regression method to test the research hypotheses and the independent variable was measured with an indicator that contains four dimensions of social responsibility. These dimensions include 45 items, and three measures were used for companies (financial performance, market 
performance, "company value", cost of capital), and four tuning variables. One of the most important results of the research is that the social contribution at the overall level has a positive impact on financial performance, company value, cost of equity, cost of borrowing, and a negative impact on the cost of capital. With regard to disclosure items (society, employees, environment, customers), the impact was negative to disclose social work on financial performance and the cost of borrowing. There is also a negative impact of employee disclosure on the value of the company, the cost of capital, the cost of borrowing, a negative effect of disclosing the product on the cost of equity only, and there is negative impact of disclosure of environmental work on the value of the company. There was no impact on the financial performance, and the study recommended the issuance of legislation and laws that obligate enterprises to issue social responsibility reports, reviewed by the external auditor, and to punish the establishments that did not issue these reports and recommended studying and testing the impact of the accounting disclosure of social responsibility on other characteristics of the company, such as stock returns. The added value, the market value to the book value on another sample in order to enrich the research process.

Hashem Abdullah (2021) study entitled: "Accounting Disclosure Reflection on Social Responsibility in Evaluating the Performance of Economic Units."

The aim of the research is to clarify the role of accounting disclosure about social activities in evaluating the performance of economic units. The research was conducted in one of the general directorates of the Iraqi Ministry of Electricity, which is the General Directorate of Electricity Distribution of Rasaffa for three years $(2015,2016$, 2017), and one of the most important recommendations of the research is the need to enact laws and instructions that oblige economic units to pay attention to social performance and allocate the necessary amounts in the state's general budget. And disclose them in the financial statements in order to reach the goal of social responsibility, which is to achieve the gains that can be obtained, because these units are in their nature units aimed at achieving profi

\section{Study Methodology}

\section{Introduction}

The methodology of the study, the most prominent actions taken by the researcher to implement the study, these procedures include defining the study population, the methods that were used to collect the data needed by this study, the statistical methods applied to analyze the data and the results that were reached.

\subsection{Study Community}

This study was conducted on all services corporations listed on the Amman Stock Exchange and written in the official list of these companies. The number of these companies reached 56 until the end of 2019, and they were distributed among all services sectors

All Jordanian services corporations listed on the Amman Stock Exchange were included in the study sample, and companies that did not meet the following conditions were excluded:

1) That the company was traded in the financial market during the study period.

2) The company has all the data necessary to calculate the study variables, which are related to the study model variables, for the entire period (2012-2019).

After applying the mentioned conditions to all services companies, "19" services corporations were excluded, and "37" services corporations accepted (Appendix No. (1))

\subsection{Study Approach}

The descriptive-analytical approach was adopted, where the data on the study variables related to the Jordanian services corporations listed on the Amman Stock Exchange were collected, then the data was analyzed and hypotheses applied to test them to reach the results and determine the appropriate recommendations.

\subsection{Sources of Data Collection}

The data of the study consisted of the following:

- Primary Sources: Data related to the study variables were collected by referring to the annual reports issued by the Jordanian services corporations listed on the Amman Stock Exchange for the period (2012-2019).

- Secondary sources: University theses, research presented in conferences, seminars, studies, and working papers published in refereed scientific and professional journals, in addition to books and websites, were used. 


\subsection{Measuring Study Variables}

The study variables that were focused on were divided into (independent variable, modifier variable, dependent variable), and the variables were measured as follows:

The independent variable: the costs of social responsibility; It was measured based on the financial costs disclosed by the companies in the reports, which relate to the following dimensions:

1) Human resources: it includes items related to supporting, training, and motivating human resources.

2) The environment, which includes items related to preserving the environment and energy resources in society.

3) The community dimension, which includes items related to supporting the local community and charitable and community associations.

4) After product development, it includes items related to developing relationships with customers and improving and developing its products.

5) Social responsibility disclosure. It was measured by a checklist, where this aspect was dealt with as a dummy variable $(0,1)$. It is mentioned that financial and non-financial disclosures of companies were dealt with.

Dependent variable: The market value of companies was measured according to the following equation:

Market value $=$ Ordinary share price on 12/31* Number of ordinary shares subscribed

The modified variable: the type of services, and it contains the following sub-sectors (pharmaceuticals and medical industries, chemical industries, food and beverages, tobacco and cigarettes, extractive and mining industries, engineering and construction industries, electrical industries, clothing, leather, and textile industries).

\subsection{The Statistical Tools Used}

The SPSS software was used to process the primary data, as well as the following statistical tests and measures:

1) Percentages, frequencies, arithmetic averages, and standard deviations in order to describe the study variables.

2) The coefficient of linear correlation and the coefficient of inflation of variance to test the phenomenon .

3) Multifetal regression analysis in order to test the influence of the independent variables on the dependent variable.

4) Structural regression analysis (choice hierarchical multiple regression) for the modified variable tests.

\section{Hypothesis Testing and Results}

\section{Introduction:}

This chapter talks about the results of data analysis for the study, where a description of the it's variables is explained, a test of data fit for it model and then testing the hypotheses

\subsection{Description of the Study Variables}

This part of the analysis presents the descriptive statistics of the study's dependent, independent, and average variables, based on the annual financial statements of services corporations listed on the Amman Stock Exchange for the period (2019 - 2012).

\section{First: the dependent variable, market value:}

Table 1 shows the arithmetic averages and standard deviations of the market value of the services corporations listed on the Amman Stock Exchange during the study period (2012-2019). 
Table 1. Descriptive statistics of the level of market value of services corporations during the period (2012-2019)*

\begin{tabular}{lcccc}
\hline Year & lowest value & highest value & SMA & standard deviation \\
\hline 2012 & 0.515 & 3875.120 & 158.938 & 648.507 \\
2013 & 1.007 & 2337.070 & 111.456 & 390.539 \\
2014 & 2.041 & 1624.701 & 90.335 & 276.151 \\
2015 & 1.157 & 1749.678 & 91.564 & 296.823 \\
2016 & 1.820 & 1598.039 & 88.701 & 284.329 \\
2017 & 1.564 & 1403.908 & 89.609 & 273.618 \\
2018 & 1.288 & 1334.754 & 82.176 & 249.981 \\
2019 & 0.990 & 1703.853 & 89.386 & 300.432 \\
the sample as a whole & 0.515 & 3875.120 & 100.271 & 358.039 \\
\hline
\end{tabular}

*Nearest million

We note from Table 1 that the general arithmetic average of the level of market value in Jordanian services corporations for the period (2012-2019), amounted to (100.271), with a standard deviation of (358.039), Figure (1-4) illustrates this results.

\section{Second: The independent variables}

\section{The level of social responsibility disclosure:}

Table 2 shows the arithmetic averages and standard deviations of the level of social responsibility disclosure with its perspectives (human resources, environment, society, product development) among Jordanian services corporations listed on the Amman Stock Exchange during the years 2012-2019 as follows:

Table 2. Descriptive statistics for the level of social responsibility disclosure in relation to human resources for services corporations during the period (2012-2019)

\begin{tabular}{lcccc}
\hline Year & lowest value & highest value & SMA & standard deviation \\
\hline 2012 & $9.0 \%$ & $82.0 \%$ & $48.9 \%$ & $14.1 \%$ \\
2013 & $18.0 \%$ & $80.0 \%$ & $49.9 \%$ & $12.8 \%$ \\
2014 & $27.0 \%$ & $82.0 \%$ & $51.6 \%$ & $11.9 \%$ \\
2015 & $27.0 \%$ & $79.0 \%$ & $51.1 \%$ & $12.4 \%$ \\
2016 & $27.0 \%$ & $82.0 \%$ & $50.4 \%$ & $13.0 \%$ \\
2017 & $27.0 \%$ & $80.0 \%$ & $52.3 \%$ & $14.9 \%$ \\
2018 & $27.0 \%$ & $81.0 \%$ & $53.1 \%$ & $14.8 \%$ \\
2019 & $18.0 \%$ & $82.0 \%$ & $52.8 \%$ & $14.7 \%$ \\
Total & $8.0 \%$ & $82.0 \%$ & $51.3 \%$ & $13.5 \%$ \\
\hline
\end{tabular}

We note from Table (4-2) that the general arithmetic mean of the level of social responsibility disclosure with regard to the dimension of human resources in the Jordanian services corporations for the period (2012-2019), amounted to (51.3\%), with a standard deviation (13.5\%), and the figure shows (4-2) Disclosure number for social responsibility regarding the dimension of human resources for Jordanian services corporations during the period (2012-2019). 


\section{Disclosure of the environment}

Table 3. Descriptive statistics of the level of social responsibility disclosure with regard to the environment dimension for services corporations during the period (2012-2019)

\begin{tabular}{lcccc}
\hline Year & lowest value & highest value & SMA & standard deviation \\
\hline 2012 & $0.0 \%$ & $100 \%$ & $82.9 \%$ & $29.0 \%$ \\
2013 & $0.0 \%$ & $100 \%$ & $83.8 \%$ & $29.0 \%$ \\
2014 & $0.0 \%$ & $100 \%$ & $80.2 \%$ & $31.9 \%$ \\
2015 & $0.0 \%$ & $100 \%$ & $81.1 \%$ & $32.0 \%$ \\
2016 & $0.0 \%$ & $100 \%$ & $81.1 \%$ & $30.0 \%$ \\
2017 & $0.0 \%$ & $100 \%$ & $82.0 \%$ & $29.0 \%$ \\
2018 & $0.0 \%$ & $100 \%$ & $81.1 \%$ & $30.0 \%$ \\
2019 & $0.0 \%$ & $100 \%$ & $82.0 \%$ & $30.0 \%$ \\
Total & $0.0 \%$ & $100 \%$ & $81.8 \%$ & $29.8 \%$ \\
\hline
\end{tabular}

We note from Table 3 that the general arithmetic average of the level of social responsibility disclosure with regard to the environmental dimension in the Jordanian services corporations for the period (2012-2019) amounted to (81.8\%), with a standard deviation of (29.8\%), figure (4-3) shows the social responsibility disclosure number with regard to the environmental dimension in Jordanian services corporations for the period (2012-2019).

\section{Disclosure of the Social Dimension}

Table 4. Descriptive statistics for the level of social responsibility disclosure with regard to the social dimension for services corporations during the period (2012-2019)

\begin{tabular}{lcccc}
\hline Year & lowest value & highest value & SMA & standard deviation \\
\hline 2012 & $0.0 \%$ & $84.6 \%$ & $29.5 \%$ & $17.4 \%$ \\
2013 & $0.0 \%$ & $69.2 \%$ & $31.0 \%$ & $17.1 \%$ \\
2014 & $0.0 \%$ & $76.9 \%$ & $32.6 \%$ & $17.9 \%$ \\
2015 & $0.0 \%$ & $69.2 \%$ & $31.8 \%$ & $16.6 \%$ \\
2016 & $0.0 \%$ & $69.2 \%$ & $32.0 \%$ & $18.3 \%$ \\
2017 & $0.0 \%$ & $69.2 \%$ & $32.0 \%$ & $17.4 \%$ \\
2018 & $0.0 \%$ & $69.2 \%$ & $32.4 \%$ & $16.2 \%$ \\
2019 & $0.0 \%$ & $69.2 \%$ & $31.0 \%$ & $14.3 \%$ \\
Total & $0.0 \%$ & $84.6 \%$ & $31.5 \%$ & $16.8 \%$ \\
\hline
\end{tabular}

We note from Table 4 that the general arithmetic mean of the level of social responsibility disclosure with regard to the social dimension in the Jordanian services corporations for the period (2012-2019) amounted to (31.5\%), with a standard deviation of (16.8\%), and Figure (4-4) shows Social responsibility disclosure number regarding the dimension of society in Jordanian services corporations for the period (2012-2019). 
Table 5. Descriptive statistics for the level of social responsibility disclosure with regard to the development of the product for services corporations during the period (2012-2019)

\begin{tabular}{lcccc}
\hline Year & lowest value & highest value & SMA & standard deviation \\
\hline 2012 & $0.0 \%$ & $100 \%$ & $9.5 \%$ & $22.8 \%$ \\
2013 & $0.0 \%$ & $66.7 \%$ & $8.1 \%$ & $19.1 \%$ \\
2014 & $0.0 \%$ & $100 \%$ & $14.9 \%$ & $26.6 \%$ \\
2015 & $0.0 \%$ & $100 \%$ & $19.4 \%$ & $30.8 \%$ \\
2016 & $0.0 \%$ & $66.7 \%$ & $13.1 \%$ & $22.3 \%$ \\
2017 & $0.0 \%$ & $100 \%$ & $15.3 \%$ & $27 . \%$ \\
2018 & $0.0 \%$ & $100 \%$ & $11.7 \%$ & $23.5 \%$ \\
2019 & $0.0 \%$ & $100 \%$ & $16.2 \%$ & $27.6 \%$ \\
Total & $0.0 \%$ & $100 \%$ & $13.5 \%$ & $25.1 \%$ \\
\hline
\end{tabular}

We note from Table 5 that the general arithmetic average of the level of social responsibility disclosure with regard to the product development dimension in the Jordanian services corporations for the period (2012-2019) amounted to $(13.5 \%)$, with a standard deviation

\section{2- Social responsibility costs:}

Table 6 shows the arithmetic averages and standard deviations of the costs of social responsibility with respect to its dimensions "the human resources dimension, the environment dimension, the society dimension, the product development dimension" in the Jordanian industrial companies, the study sample during the period (2012-2019), as follows:

Table 6. Descriptive statistics of the level of social responsibility costs for industrial companies during the period (2012-2019)

\begin{tabular}{lll}
\hline The Dimension & SMA & Standard Deviation \\
\hline HR & 1.765171 & 4.132012 \\
The environment & 0.008376 & 0.084635 \\
Society & 0.781042 & 8.216375 \\
product development & 0 & 0 \\
The costs of social responsibility as a whole & 2.554589 & 11.31473 \\
\hline
\end{tabular}

We note from Table 6 that the general arithmetic average of the costs of social responsibility as a whole for the period (2012-2019) amounted to (2.554589), with a standard deviation of (11.31473), and the arithmetic average of the costs of social responsibility in relation to human resources was (1.765171) and with a deviation (4.132012), and the arithmetic mean of the costs of social responsibility in relation to the environment was (0.008376) and a standard deviation was $(0.084635)$. The arithmetic mean of the costs of social responsibility in relation to the development of society was (0.781042) and a standard deviation (8.216375), while the Jordanian industrial companies did not disclose the financial product development, which prompted the researcher to delete this dimension from the model for costs. The existence of a difference between the disclosure ratio and the arithmetic average of costs can be explained by the fact that most companies are satisfied with the non-financial disclosure of social responsibility clauses.

\section{Third: The modified variable (type of sector):}

Table 7 describes the modified variable (type of sector) by extracting the frequencies and percentages of the number of companies in each sub-sector within the industrial sector. 
Table 7. Frequencies and percentages of the number of companies in each sub-sector within the industrial sector

\begin{tabular}{lll}
\hline The sector & Frequencies & Percentages \\
\hline Pharmaceutical and medical industries & 3 & 8.1 \\
chemical industries & 5 & 13.5 \\
Food and drinks & 8 & 21.6 \\
Tobacco and cigarettes & 2 & 5.4 \\
Extractive and mining industries & 8 & 21.6 \\
Engineering and construction industries & 7 & 18.9 \\
electrical industries & 3 & 8.1 \\
Garment, leather, and textile industries & 1 & 2.7 \\
Total & 37 & 100 \\
\hline
\end{tabular}

We note from Table 7 that the highest percentage of the distribution of industrial companies according to the type of sector amounted to $(21.6 \%)$ for each of the sectors of food and beverages, extractive and mining industries, while the lowest percentage was $(2.7 \%)$ for the sectors of clothing, leather and textile industries.

To confirm the previous result, the Variance Inflation Factor (VI) was used between the independent variables to make sure that there is no linear multiple correlation between them.

Table 8. Results of the multiple correlation test between independent variables

\begin{tabular}{llll}
\hline Main variable & sub-variable & Tolerance & VIF \\
\hline Disclosure & HR & 0.869 & 1.151 \\
& The environment & 0.764 & 1.309 \\
& Society & 0.729 & 1.371 \\
& product development & 0.951 & 1.051 \\
\hline Costs & HR & 0.559 & 1.788 \\
& The environment & 0.888 & 1.127 \\
& Society & 0.535 & 1.868 \\
\hline
\end{tabular}

Table 8 shows that the value of the variance inflation factor for all variables was less than 5 , and this confirms that the data are free from the phenomenon of multiple linear correlation.

\section{Hypothesis testing:}

Ho1: There is no statistically significant effect $(0.05 \geq \alpha)$ for the cost of social responsibility on the market value of industrial companies listed on the Amman Stock Exchange.

This hypothesis was tested by applying the simple regression equation to study the impact of social responsibility costs on market value in industrial companies listed on the Amman Stock Exchange, after extracting the natural logarithm of the base (10) for all data, and table No. (4-9) illustrates this. 
Table 9. Simple regression equation to study the impact of the dimensions of social responsibility costs on the market value of industrial companies listed on the Amman Stock Exchange

\begin{tabular}{llllll}
\hline Dependent variable & Coefficient table & & & \\
\cline { 2 - 5 } & Report & Beat & Standard error & Calculated T & Sig t \\
\hline Market value & Constant gradient & 7.107 & 0.044 & 161.981 & 0.000 \\
\cline { 2 - 5 } & Social Responsibility Costs & 0.000 & 0.000 & 2.999 & 0.003 \\
\hline $\mathbf{R}$ & 0.172 & & & \\
\hline Coefficient of determination $\mathbf{R}^{\mathbf{2}}$ & 0.030 & & & & \\
\hline correction factor AdjR & 0.026 & & & \\
\hline calculated F-value & 8.994 & & & \\
\hline Sig. $\mathbf{F}^{*}$ & 0.000 & &
\end{tabular}

* The effect is statistically significant at the level of $(0.05 \geq \alpha)$ 。

Table 9 shows that the value of the coefficient of determination that explains the ability of social responsibility costs combined to influence the market value $\left(\mathrm{R}^{2}=0.03\right)$; this means that the independent variables have explained $3 \%$ of the variance in the market value, while keeping the other factors constant. It also shows that the value of (F) reached (8.994) at a confidence level $(\mathrm{Sig}=0.000)$.

This confirms the significance of the regression at the level of $(0.05 \geq \alpha)$. From the above, we reject the first main hypothesis in the zero form and accept the alternative formula, which states that: There is a statistically significant effect at the level of $(0.05 \geq \alpha)$ for the social responsibility costs on the market value of industrial companies listed on the Amman Stock Exchange.

The second main hypothesis: There is no statistically significant effect $(0.05 \geq \alpha)$ To disclose the social responsibility on the market value of the industrial companies listed on the Amman Stock Exchange.

This hypothesis was tested by applying the Simple Regression equation to study the impact of social responsibility disclosure on the market value of industrial companies listed on the Amman Stock Exchange, after extracting the natural logarithm of the base (10) for all data, and Table No. (4-10) shows that .

Table 10. Simple Regression Equation to Study the Impact of Social Responsibility Disclosure Dimensions on Market Value in Industrial Companies Listed on the Amman Stock Exchange

\begin{tabular}{|c|c|c|c|c|c|}
\hline \multirow{2}{*}{ Dependent variable } & \multicolumn{5}{|l|}{ Coefficient table } \\
\hline & Report & Beat & Standard error & Calculated T & Sig $\mathbf{t}^{*}$ \\
\hline \multirow[t]{2}{*}{ Market value } & Constant gradient & 6.728 & 0.139 & 48.262 & 0.000 \\
\hline & $\begin{array}{l}\text { Disclosure of social } \\
\text { responsibility }\end{array}$ & 0.918 & 0.298 & 3.080 & 0.002 \\
\hline $\mathbf{R}$ & 0.177 & & & & \\
\hline $\begin{array}{l}\text { Coefficient of determination } \\
\mathbf{R}^{2}\end{array}$ & 0.031 & & & & \\
\hline correction factor $\mathrm{Adj}^{2}$ & 0.028 & & & & \\
\hline calculated F-value & 9.488 & & & & \\
\hline Sig. $\mathbf{F}^{*}$ & 0.002 & & & & \\
\hline
\end{tabular}

* The effect is statistically significant at the level of $(0.05 \geq \alpha)$ 。

Table 10 shows that the value of the coefficient of determination that explains the ability of the social responsibility disclosure combined to influence the market value $R^{2}=0.03$ ) this means that the independent variables explained 
$3.1 \%$ of the variance in the market value with other factors remaining constant.

It also shows that the value of $(\mathrm{F})$ reached $(9.488)$ at a confidence level $(\mathrm{Sig}=0.002)$. This confirms the significance of the regression at the level of $(0.05 \geq \alpha)$. Accordingly, we reject the second main hypothesis and accept the alternative, which states that: There is a statistically significant effect at the level of significance $(0.05 \geq \alpha)$ to disclose the social responsibility on the market value of the industrial companies listed on the Amman Stock Exchange.

The third main hypothesis: There is no statistically significant effect $(0.05 \geq \alpha)$ for the variable of the type of industry on the relationship between social responsibility disclosure on the market value of industrial companies listed on the Amman Stock Exchange.

This hypothesis was tested by hierarchical regression analysis, and the results were as shown in Table 11.

Table11. Results of the hierarchical regression test for the effect of industry type on the relationship between social responsibility disclosure and market value Industrial companies listed on the Amman Stock Exchange

\begin{tabular}{|c|c|c|c|c|c|c|c|c|c|c|}
\hline Step & $\begin{array}{l}\text { Independent } \\
\text { variable }\end{array}$ & $(\beta)$ & $\begin{array}{l}\text { (t) } \\
\text { Value }\end{array}$ & sig & $\mathbf{R}$ & $\mathbf{R}^{2}$ & $\begin{array}{l}\left(\mathrm{R}^{2}\right. \\
\text { change }\end{array}$ & F-value & $\begin{array}{l}\text { F-Change } \\
\text { value }\end{array}$ & sig \\
\hline \multirow{2}{*}{$\begin{array}{l}1^{\text {st }} \\
\text { step }\end{array}$} & Constant & 6.728 & 0.139 & 48.262 & \multirow{2}{*}{0.177} & \multirow{2}{*}{0.031} & \multirow{2}{*}{0.031} & \multirow{2}{*}{9.488} & \multirow{2}{*}{9.488} & \multirow{2}{*}{0.002} \\
\hline & Disclosure & 0.918 & 0.298 & 3.080 & & & & & & \\
\hline \multirow{3}{*}{$\begin{array}{l}2^{\text {nd }} \\
\text { step }\end{array}$} & Constant & 6.543 & 0.159 & 41.263 & \multirow{3}{*}{0.223} & \multirow{3}{*}{0.050} & \multirow{3}{*}{0.018} & \multirow{3}{*}{7.637} & \multirow{3}{*}{5.637} & \multirow{3}{*}{0.018} \\
\hline & Disclosure & 0.822 & 0.298 & 2.756 & & & & & & \\
\hline & Sector Type & 0.054 & 0.023 & 2.374 & & & & & & \\
\hline
\end{tabular}

Dependent variable: market value.

It appears from Table 11 that there is a statistically significant effect at the level of $(0.05 \geq \alpha)$ at the variable of the type of service on the relationship between social responsibility disclosure and the market value of services companies that listed on the Amman Stock Exchange.

The value of the correlation coefficient between social responsibility disclosure and the market value has increased from (0.177) to (0.223), after the sector type variable was entered into the regression model to show its effect as a modified variable. It appears from Table 11 also that the value of the coefficient of determination (R-square) for the social responsibility disclosure has reached (0.031). And that the change in the coefficient of determination (R-square Change/R2-Change) for the type of sector amounted to (0.018), and the value of (F Change) reached (5.637) at a confidence level (0.000), which confirms the significance of the regression at the level of $(0.05 \geq \alpha)$; this means that the type of sector has contributed to a slight increase in the impact of social responsibility disclosure in the market value, as the interpretation increased by an estimated (0.018) of the discrepancy in the market value. It appears from Table 11 as well that the value of (F) for the first model reached (9.488) at a confidence level of (Sig=0.002), which confirms the significance of the regression at the level of $(0.05 \geq \alpha)$. As it appears from Table 11 that the value of $(F)$ for the second model reached (7.637) at a confidence level $(\mathrm{Sig}=0.018)$, which also confirms the significance of the regression at the level of $(0.05 \geq \alpha)$. From the above, it is clear that there is a statistically significant effect at the level of $(0.05 \geq \alpha)$ for the industry type average on the relationship between social responsibility disclosure and the market value of services companies listed on the Amman Stock Exchange.

From the above, we reject the third main hypothesis in the zero form and accept the alternative formula, which states that: There is a statistically significant effect at the level of significance $(0.05 \geq \alpha)$ Regarding the services type rate on the relationship between the disclosure of social responsibility and the market value of the services companies listed on the Amman Stock Exchange.

\section{Results and Recommendations}

In the first part of this chapter, the researcher presents the most important results that he obtained through conducting statistical analysis, and in the second chapter he presents the recommendations that the researcher believes are important and necessary to improve the results included in the current study if they were applied later.

\subsection{Study Results}

1) There is an impact of social responsibility costs on the market value of services companies listed on the Amman 
Stock Exchange, and the researcher attributes this result to that services sector companies seek to reduce the levels of risk they may be exposed to in order to improve their image before the local community, as disclosure of the costs of social responsibility contributes to improving the societal outlook, especially as it has a positive impact on the environment. These companies work to meet the needs and expectations of stakeholders.

2) There is a statistically significant effect at the significance level $(0.05 \geqslant \alpha)$ to social responsibility disclosure on the market value in the services companies listed on the Amman Stock Exchange, and the researcher attributes this result to the interest in the company's social responsibility disclosure, and the disclosure of the activities used by the company, especially services companies, play an important role in attracting a larger number of investors and customers, given To increase the importance of social responsibility for all who are affected by what the company does. The researcher also believes that services companies, which are considered by many investors and customers- The source that causes a high degree of pollution the environment should pay attention to the practices and activities of social responsibility; In order to give a good image about the company in order to reduce pollution levels and contribute to the development of local communities.

3) There is an effect of the average type of industry on the relationship between the social responsibility disclosure and the market value of servuces companies listed on the Amman Stock Exchange, and this result can be explained that services companies, regardless of the nature of their work, are subject to the same laws and regulations, and they are equally concerned with improving their societal image.

\subsection{Recommendations}

Based on what was mentioned previously, the study recommends the following:

1) Increasing practices related to social responsibility, which helps in strengthening confidence in the company as a strong and desirable organization and enhances the value of the company and its services to customers.

2) Encouraging industrial companies to prepare and adopt clear policies to reduce the consumption of environmental resources such as water, energy, and others, and disclose them.

3) Focus on disclosing the product development dimension, which enables the company to optimally exploit raw materials by accurately determining the characteristics and qualities of the materials required for production.

4) The need for companies to apply social responsibility accounting in all its aspects and use it as an information system that serves all relevant parties.

5) Requiring industrial companies to clearly prepare reports on social performance, in addition to the final financial reports.

6) Conducting studies similar to this study on other sectors to identify the relationship between the practice of social responsibility and market value.

\section{References}

Al-Banat, E. (2017). Accounting for social responsibility and its role in supporting the competitive advantage of commercial enterprises in the market, a field study on the Zain Sudan Telecom Company (a master's thesis, Al-Neelain University, College of Graduate Studies, p. 39).

Al-Hammouri, S., \& Al-Maaytah, R. (2015). Corporate Social Responsibility (1st ed.). Jordan - Amman: Dar Al-Hamid for Publishing and Distribution.

Al-Olimat, N. A. (2010). Accounting measurement of the costs of social responsibility activities and their disclosure in the final financial statements (Applied case on the Jordan Petroleum Refinery Company, a public shareholding company, PhD thesis in accounting, Department of Graduate Studies, Faculty of Economics, Damascus University, pp. 20-21).

Al-Sawalhi, W. (2017). The impact of the announcement of interim financial reports on the market value of the shares of Jordanian commercial banks (a master's thesis, Amman Arab University - Jordan).

Al-Sharif, M. (2014). The impact of social and environmental performance on the market value of the Jordanian company, an applied study on industrial public shareholding companies listed on the Amman Stock Exchange (unpublished doctoral thesis, University of Islamic Sciences, Amman - Jordan.

Al-Shatnawi, H. (2018). The effect of disclosing non-financial information on the quality of financial reports and the market value of Jordanian commercial banks, "Applied". Journal of the Islamic University of Economic and Administrative Studies, 26(3). 
Al-Sufi, F. J., Al-Qutaish, H. F., \& Qaraqish, J. (2012). The importance of costs and environmental disclosure in rationalizing administrative decisions in industrial public shareholding companies. Journal of Baghdad College of Economic Sciences, 13.

Dhafi, N. (2010). Corporate Social Responsibility and Human Resources. Master's Thesis.

Gumaa, M. (2017). The impact of Jordanian companies' adoption of social responsibility on their financial performance: An applied study on companies listed on the Amman Stock Exchange (an unpublished master's thesis, College of Business, Middle East University).

Haddad, F. (2014). Financial Management (4th ed.). Jordan - Amman: Dar Al-Hamid for Publishing and Distribution.

Halima, B. Q. (2016). A study of the impact of financial performance indicators on the market value of the stock, study of the Qatar Stock Exchange for the period (2010-2015) (a master's thesis, Faculty of Economics, Commercial Sciences and Management Sciences, Qasdi Merbah University - Ouargla).

Issa, M. (2019). The Impact of Disclosure of Governance and Social Responsibility on the Market Value of Industrial Companies Listed in the Amman Stock Exchange (Unpublished Master's Thesis, College of Business, Middle East University).

Jassim, B., Abboud, F., et al. (2020). The role of accounting disclosure of social costs on consumer purchasing decisions (applied research in a sample of Iraqi industrial companies). Journal of the College of Administration and Economics for Economic, Administrative and Financial Studies, 12(1).

Khamera, Al-T. (2007). Environmental and social responsibility, an introduction to the contribution of the economic institution to achieving sustainable development, "The Case of Sonatraq" (a memorandum submitted to complete the requirements of the master's degree in economic sciences, Faculty of Law and Economic Sciences, Qasdi Merbah University of Ouargla).

Odeh, I. M. (2008). Measuring social costs and their contribution to achieving social well-being: a free application study on five-star hotels in Jordan (Faculty of Administrative Finance, Middle East University for Graduate Studies).

Omar, B., Al-Shaar, I., \& Zalloum, N. (2014), The Impact of Disclosure of Social Responsibility Accounting on the Financial Performance of Jordanian Public Shareholding Industrial Companies. Journal of Administrative Sciences Studies, 2(4), 240-285.

Sabri, A. A. (2011). Disclosure by Saudi joint stock companies of social responsibility in their financial reports, an applied study. Journal of Business Research, 33(2), 180.

Salehi, S. (2015). The Contribution of Social Responsibility in Strengthening the Competitive Advantage (Master Thesis, University of Mohamed Khider, Biskra, Algeria).

Shaheen, A. (2011). Accounting Theory (Intellectual, Analytical and Applied Framework) (1st ed.). Afaq Library for Printing, Publishing and Distribution, Gaza, opposite the Islamic University.

Shirazi, A. M. (2010). Accounting Theory. Kuwait: Dar Al Salasil for Publishing.

\section{Copyrights}

Copyright for this article is retained by the author(s), with first publication rights granted to the journal.

This is an open-access article distributed under the terms and conditions of the Creative Commons Attribution license (http://creativecommons.org/licenses/by/4.0/). 